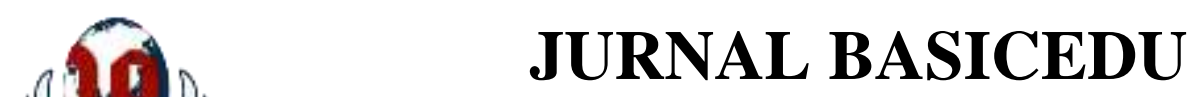

Volume 5 Nomor 5 Tahun 2021 Halaman 3498 - 3512

Research \& Learning in Elementary Education

https://jbasic.org/index.php/basicedu

PAVERSITAS

\title{
Pengembangan E-Media Nearpod melalui Model Discovery untuk Meningkatkan Kemampuan Berpikir Kritis Siswa di Sekolah Dasar
}

\author{
Tri Adi Susanto \\ Magister Pendidikan Dasar, Univeristas Muria Kudus, Indonesia \\ E-mail: triadisusanto.ppg@gmail.com
}

\begin{abstract}
Abstrak
Menyadari pembelajaran belum efektif dan inovatif sehingga kemampuan berpikir kritis siswa masih rendah, dibutuhkan penelitian untuk meningkatkan rendahnya kemampuan berpikir kritis siswa. Penelitian pengembangan ini bertujuan menganalisis kelayakan dan efektivitas pengembangan E-Media Nearpod melalui Model Discovery untuk meningkatkan kemampuan berpikir kritis siswa kelas V sekolah dasar. Penelitian pengembangan ini bertujuan menganalisis kelayakan dan efektivitas pengembangan E-Media Nearpod melalui Model Discovery untuk meningkatkan kemampuan berpikir kritis siswa. Pengumpulan data menggunakan teknik tes, observasi, wawancara, dan angket. Analisis data dalam penelitian ini adalah validasi produk E-Media Nearpod dan N-gain untuk mengukur efektivitas produk dalam meningkatkan kemampuan berpikir kritis. Dari hasil validasi oleh validator ahli materi diperoleh nilai 85\% kategori sangat layak, sedangkan dari ahli media diperoleh nilai $84 \%$ kategori sangat layak. E-Media Nearpod melalui Model Discovery diterapkan pada kelas eksperimen yang berjumlah 57 siswa kelas V sekolah dasar di wilayah Desa Jatiharjo Kabupaten Grobogan. Hasil uji efektivitas produk, diperoleh N-gain 0,42 kriteria sedang sehingga penggunaan E-media Nearpod melalui Model Discovery efektif dalam meningkatkan kemampuan berpikir kritis siswa. Disimpulkan dalam penelitian pengembangan E-media Nearpod melalui Model Discovery dalam pembelajaran sangat layak dan efektif meningkatkan kemampuan berpikir kritis siswa.
\end{abstract}

Kata Kunci: Pengembangan, E-media, Nearpod, Discovery, Berpikir Kritis.

\begin{abstract}
Realizing that learning has not been effective and innovative so that students' critical thinking skills are still low, research is needed to improve the low critical thinking skills. This development research aims to analyze the feasibility and effectiveness of developing E-Media Nearpod through Model Discovery to improve the critical thinking skills of fifth grade elementary school students. This development research aims to analyze the feasibility and effectiveness of developing EMedia Nearpod through Model Discovery to improve students' critical thinking skills. Collecting data using test techniques, observation, interviews, and questionnaires. The data analysis in this study is the validation of the E-Media Nearpod and $N$-gain products to measure the effectiveness of the product in improving critical thinking skills. From the results of the validation by the material expert validator, it was obtained a value of $85 \%$ in the very feasible category, while from the media expert the score was $84 \%$ in the very feasible category. E-Media Nearpod through Model Discovery was applied to the experimental class, which consisted of 57 fifth grade elementary school students in the Jatiharjo Village area, Grobogan Regency. The results of the product effectiveness test, obtained an $N$-gain of 0.42 moderate criteria so that the use of Nearpod E-media through the Discovery Model is effective in improving students' critical thinking skills. It was concluded that the Nearpod E-media development research through the Discovery Model in learning was very feasible and effective in improving students' critical thinking skills.
\end{abstract}

Keywords: Development, E-media, Nearpod, Discovery, Critical Thinking.

Copyright (c) 2021 Tri Adi Susanto

$\triangle$ Corresponding author :

Email : triadisusanto.ppg@gmail.com

DOI : https://doi.org/10.31004/basicedu.v5i5.1399

ISSN 2580-3735 (Media Cetak)

ISSN 2580-1147 (Media Online)

Jurnal Basicedu Vol 5 No 5 Tahun 2021

p-ISSN 2580-3735 e-ISSN 2580-1147 


\section{PENDAHULUAN}

Menuju masyarakat dengan tatanan baru di era modern ini sangat berpengaruh terhadap karakter setiap manusia termasuk para siswa. Tidaklah mudah menyesuaikan dengan kecakapan abad 21 dengan tetap mempertahankan profil pelajar Pancasila. Selain harus memiliki kecakapan abad 21, yaitu: (1) kecakapan belajar dan berinovasi; (2) kecakapan menggunakan teknologi komunikasi; dan, (3) kecakapan hidup untuk bekerja dan berkontribusi pada masyarakat, para siswa harus tetap memiliki profil pelajar Pancasila. Profil pelajar Pancasila yang harus tampak dan dimiliki oleh setiap siswa, yaitu: (1) beriman dan bertakwa kepada Tuhan Yang Maha Esa serta berakhlak mulia; (2) berkebhinekaan global; (3) mandiri; (4) bernalar (berpikir) kritis; (5) kreatif; dan, (6) gotong royong.

Adanya perubahan tatanan yang terjadi di masyarakat seperti yang dikemukakan, mau tidak mau guru harus bangkit untuk meningkatkan kompetensinya dalam inovasi pembelajaran. Kemampuan guru dalam mendesain pembelajaran yang mampu beradaptasi dengan kemajuan teknologi komunikasi dan informasi sangat diharuskan. Guru harus mengikuti berbagai kegiatan pelatihan, workshop, bimtek maupun menempuh studi lanjut yang dapat meningkatkan kompetensinya.

Selain peningkatan kompetensi guru, kemampuan dalam mendesain pembelajaran, termasuk memilih media yang tepat juga berpengaruh terhadap keberhasilan pembelajaran. Pemilihan media yang tepat dapat menjembatani tercapainya tujuan pembelajaran. Salah satu jenis media era sekarang yaitu E-Media. Pengembangan media pembelajaran sangat penting seperti yang dikemukakan oleh (Musfiqon, 2012) dengan pendapatnya yaitu untuk mencapai keberhasilan pembelajaran maka diperlukan media pembelajaran. Dalam pembelajaran semua komponennya saling berkaitan satu sama lain dan saling mendukung. Berbagai komponen pembelajaran seperti: guru, strategi, materi, media, bahan ajar, evaluasi, siswa dan sarana pendukung sangat berkaitan.

Pemilihan media yang tepat dapat menentukan keberhasilan pembelajaran. Hal ini sesuai dengan yang dikemukakan olah (Mustika, 2015) bahwa kedudukan media sangat penting dan menentukan untuk membantu guru dan siswa dalam proses pembelajaran. Pada dasarnya media ini adalah perantara yang menjembatani informasi (materi pembelajaran) dari berbagai sumber belajar yang disampaikan guru sebagai penyalur pesan kepada siswa sebagai penerima pesan untuk mencapai tujuan pembelajaran yang hendak dicapai.

Berbagai E-media yang dapat dimanfaatkan dan dikembangkan sangat beragam. Ada yang berupa aplikasi Zoom meting atau Google meet untuk proses pembelajaran secara daring sinkron. Bahan ajar elektronik yang berupa aplikasi berbasis android ataupun hosting dan domain yang dapat digunakan untuk pembelajaran daring asinkron. Adapun yang digunakan untuk membuat aplikasi sangat beragam tergantung kebutuhan termasuk dalam pengembangan media dapat dipilih secara terintegrasi dari berbagai aplikasi yang saling mendukung. Adapun dalam penelitian ini dideskripsikan mengenai pengembangan pembelajaran melalui aplikasi E-media Nearpod.

Pembelajaran yang variatif dan kolaboratif melalui berbagai model pembelajaran termasuk dengan salah satu model pembelajaran yaitu Discovery masih relevan dengan pengembangan kompetensi abad ke-21 yang harus dikuasai siswa. Hal ini sejalan dengan kemampuan kolaboratif yang dapat dibelajarkan melalui model Discovery. Melalui model ini siswa belajar secara terarah, terstruktur dan mandiri dengan kegiatan ilmiah dan berbagi tugas serta dapat melatih kemampuan berpikir kritis. Model ini merupakan model pembelajaran yang lebih cenderung menggunakan pendekatan saintifik dan konstruktivisme. Penerapannya yaitu siswa sebagai pusat belajar dan guru berperan sebagai fasilitator. Dalam paradigma pembelajaran yang baru, guru bukanlah satu-satunya sumber belajar. Sebagai fasilitator belajar, guru diharapkan dapat lebih kreatif dan inovatif dalam merencanakan dan melaksanakan pembelajaran.

Langkah-langkah atau sintaks dari model Discovery ini seperti yang dikemukakan oleh (Widhiyantoro et al., 2012), langkah-langkah operasional dalam mengaplikasikan metode discovery learning di kelas yaitu: 
stimulation (pemberian rangsangan), problem statement (pertanyaan/identifikasi masalah), data collection (pengumpulandata), data processing (pengolahan data), verification (pembuktian) dan generalization (menarik kesimpulan/generalisasi).

Dengan pengembangan E-media Nearpod melalui model Discovery dimaksudkan untuk meningkatkan kemampuan berpikir kritis. Berpikir kritis merupakan salah satu kompetensi abad ke-21 yang harus dikuasai dan dikembangkan oleh siswa. Sebagai salah salah satu kompetensi abad 21, berpikir kritis atau critical thinking memiliki banyak definisi. Menurut para ahli seperti Beyer dalam (Siswa et al., 2012) yang mengemukakan bahwa berpikir kritis adalah sebuah cara berpikir disiplin yang digunakan seseorang untuk mengevaluasi validitas sesuatu (pernyataan-penyataan, ide-ide, argumen, dan penelitian). Mengacu pada pendapat beberapa ahli tersebut dapat disarikan bahwa berpikir kritis yaitu cara berpikir dengan penuh disiplin melalui pola pikir atau daya nalar yang cerdas berkaitan dengan konsep, disertai dengan analisis, sintesis dan evaluasi dan dikomunikasikan melalui argumen atau tindakan yang dapat dipercaya.

Mengenai kemampuan berpikir kritis siswa, kebanyakan siswa masih lambat untuk berpikir kritis karena belum terbiasa dan terlatih. Siswa masih banyak yang memiliki kemampuan berpikir tingkat rendah atau kita mengenalnya dengan LOTS (low order thinking skill) hanya sebagian kecil yang memiliki kemampuan berpikir tingkat tinggi atau HOTS (higt order thinking skill). Sebagai salah satu kemampuan yang harus dikuasai siswa pada abad 21 ini maka diperlukan suatu pembelajaran yang dapat memotivasi dan meningkatkan daya nalar agar siswa dapat mencapai perkembangan konnitif C3, C4, C5 bahkan C6 sehingga tidak hanya dapat mencapai level $\mathrm{C} 1$ dan $\mathrm{C} 2$ saja.

Sebuah penelitian yang telah dilakukan oleh (Yulianti et al., 2014) mengemukakan bahwa secara empiris, media Word Square berbantu kartu UNO memiliki implikasi dapat meningkatkan kemampuan berpikir kritis siswa. Dengan tampilan desain dan isi media Word Square berbantu kartu UNO menjadikan siswa tertantang untuk berpikir tingkat tinggi dalam menyelesaikan tugasnya. Sesuai pendapat ini maka dalam penelitian pengembangan ini sangat optimis dapat meningkatkan kemampuan berpikir kritis siswa dengan EMedia Nearpod melalui Model Discovery dalam pembelajaran. Pengembangan yang dilakukan yaitu pada bahan ajar dan evaluasi.

Selain dari beberapa hal yang dikemukakan, dari hasil pengamatan terhadap sekolah dasar di wilayah Desa Jatiharjo Kecamatan Pulokulon Kabupaten Grobogan dan dari hasil analisis kebutuhan yang diperoleh dari wawancara dan angket, diperlukan suatu media belajar yang tepat untuk meningkatkan kemampuan berpikir kritis siswa. Hal ini relevan dengan kondisi di mana pembelajaran harus berlangsung secara daring. Pertimbangan lainnya, ada beberapa penelitian terdahulu yang dilakukan oleh (Riyanti, 2020) yang berjudul: "Pengembangan Perangkat Pembelajaran Project Based Learning (PjBL) Terintegrasi STEM Berbasis ELearning untuk Peningkatan Kemampuan Berpikir Kreatif Siswa". Dari hasil penelitiannya, memperoleh hasil bahwa (1) perangkat pembelajaran yang dikembangkan layak untuk digunakan yang berupa: silabus, bahan ajar, RPP; (2) perangkat pembelajaran project-based learning terintegrasi STEM berbasis e-learning efektif dalam meningkatkan kemampuan berpikir kreatif siswa; dan (3) tanggapan guru mendapatkan respon sangat baik. Penggunaan bahan ajar project-based learning terintegrasi STEM menjadi salah satu solusi untuk meningkatkan kemampuan berpikir kreatif pada siswa. Hasil penelitian terdahulu ini merupakan rujukan dalam penelitian ini.

Dari berbagai hal yang telah dipaparkan tersebut, dan dari hasil analisis kebutuhan, dalam penelitian pengembangan ini yang menjadi dasar peneliti mengambil topik mengenai E-Media Nearpod melalui Model Discovery untuk meningkatkan kemampuan berpikir kritis siswa yaitu bahwa pembelajaran yang bermakna, aktif, efektif, inovatif dan menyenangkan belum diterapkan dengan baik. Hal ini menyebabkan kemampuan berpikir kritis siswa masih rendah. Untuk itu peneliti mencoba mengadakan penelitian pengembangan ini agar dapat menghasilkan produk yang bermanfaat bagi peningkatan pembelajaran yang berupa Nearpod sebagai media belajar daring. 
Penelitian pengembangan ini bertujuan menganalisis kelayakan dan efektivitas pengembangan untuk meningkatkan kemampuan berpikir kritis siswa. Untuk mencapai tujuan tersebut, dikembangkan perangkat pembelajaran E-Media yang berupa Nearpod sebagai media belajar daring untuk memberikan bahan dan evaluasi belajar. Pelaksanaan pembelajaran melalui penerapan model pembelajaran Discovery dengan perangkat pembelajarannya untuk meningkatkan kemampuan berpikir kritis siswa. Komponen-komponen perangkat pembelajaran yang dikembangkan berupa bahan ajar dirancang secara daring (media digital). Cakupan materi adalah tema 7 kelas V sekolah dasar sesuai dengan kurikulum yang berlaku yaitu kurikulum 2013. Evaluasi soal dilakukan secara daring dan luring menyesuaikan kondisi. Seperti sekarang ini di mana pembelajaran harus dilakukan secara daring maka sebuah media seperti E-Media Nearpod sangat diperlukan. Pembelajaran dapt dikemas melaui sebuah metode. Dalam penelitian ini dipilih Model Discovery karena memiliki kelebihan seperti membantu siswa mangembangkan atau memperbanyak persediaan dan penguasaan ketrampilan dan proses kognitif siswa, dapat membangkitkan keinginan atau gairah pada siswa, menjadikan cara belajar siswa terarah, menambah percaya diri untuk mampu mengatasi kondisi yang ada serta pembelajaran berpusat pada siswa.

Dari hasil pengamatan (observasi), wawancara dan data dokumen hasil belajar ada berbagai masalah serta dari analisis kebutuhan diperoleh beberapa masalah yang selama ini banyak muncul yaitu: (1) pembelajaran yang dikelola oleh guru terkesan konvensional dan monoton serta belum menerapkan pembelajaran yang bermakna, aktif, efektif, inovatif dan menyenangkan belum dilaksanakan; (2) media yang digunakan dalam proses pembelajaran belum efektif dan kurang menarik; (3) perlunya pengembangan EMedia untuk menyesuaikan dengan kemajuan iptek saat ini, dan, (4) kemampuan berpikir kritis siswa rendah.

Walaupun banyak yang telah dilakukan oleh para peneliti dalam meningkatkan kemampuan berpikir kritis siswa namun dalam penelitian pengembangan ini dicoba untuk menerapkan E-media Nearpod melalui Model Discovery Kebutuhan akan media sangat relevan untuk kondisi saat ini. Ada beberapa karakteristik yang menjadi alasan mengapa E-media Nearpod dipilih. Karakteristik E-media Nearpod antara lain berbasis komputer dan web, yaitu melalui jaringan internet dan menggunakan berbagai aplikasi digital yang saling mendukung. Selain itu, keunggulan E-media Nearpod antara lain flleksibel karena bisa diakses di mana saja asalkan memiliki jaringan internet, memungkinkan terjadinya pembelajaran secara interaktif (teleconference dan virtual), dapat dioperasikan di HP maupun PC dan dapat digunakan secara mandiri oleh siswa serta penggunaannya tidak terbatas pada ruang dan waktu.

\section{METODE PENELITIAN}

Desain penelitian ini menggunakan model Research and Development $(R \& D)$ atau penelitian dan pengembangaan. Sesuai pendapat dari Sugiyono dalam (Kusumayadi, 2020) dapat dikemukakan bahwa model penelitian ini merupakan suatu penelitian yang menghasilkan suatu produk yang digunakan dan berfungsi secara luas di masyarakat setelah dilakukan pengujian kefektifan produk dan dilakukan penelitian untuk uji coba produk tersebut.

Seperti dalam penelitian-penelitian pengembangan lain, diperlukan kegiatan untuk mengembangkan atau memvalidasi hasil produk yang dimanfaatkan dalam pendidikan dan pembelajaran. Dalam penelitian ini, produk yang dikembangkan berupa E-Media Nearpod yang dalam pelaksanaannya melalui model Discovery untuk meningkatkan kemampuan berpikir dan kemandirian siswa. Sebagai E-Media, Nearpod sudah ada namun perlu dikembangkan untuk pendidikan dan pembelajaran yang disesuaikan pada jenjang pendidikan sekolah dasar sehingga produk pengembangannya benar-benar dapat dimanfaatkan secara praktis.

Prosedur penelitian mengacu pada langkah-langkah Borg and Gall. Mengacu pada pendapatnya dalam (Mubasiroh, 2013) melalui bukunya yang berjudul Educational Research, langkah-langkah yang digunakan dalam penelitian ini yaitu sebagai berikut: (1) Observasi dan Pengumpulan Informasi); (2) Perencanaan; (3) 
3502 Pengembangan E-Media Nearpod melalui Model Discovery untuk Meningkatkan Kemampuan Berpikir Kritis Siswa di Sekolah Dasar - Tri Adi Susanto

DOI: https://doi.org/10.31004/basicedu.v5i5.1399

Pelaksanaan (Pengembangan Draf Produk); (4) Pemantapan; (5) Penilaian produk oleh ahli; (6) Perbaikan dan penyempurnaan produk awal; (7) Penilaian produk hasil penelitian; dan, (8) Penyempurnaan Produk Akhir.

Sumber data dalam penelitian ini adalah guru dan siswa Kelas V sekolah dasar di Wilayah Desa Jatiharjo Kabupaten Grobogan pada tahun pelajaran 2021/2022. Kelas eksperimen terdiri atas 4 kelas dengan jumlah keseluruhan 57 siswa. Selain itu didukung data responden dari ahli materi dan ahli media yang memvalidasi kelayakan dari E-Media Nearpod yang dikembangkan. Untuk pengumpulan data, dalam penelitian ini menggunakan tahap validasi, sedangkan untuk mengetahui efektivitas produk yang dikembangkan dilakukan tahap praktikalitas dengan mengimplementasikan dalam pembelajaran melalui model Discovery yang selanjutnya dilakukan evaluasi akhir berupa tes pada muatan pelajaran IPA untuk mengetahui peningkatan kemampuan berpikir kritis siswa yang selanjutnya diukur efektivitas dengan membandingkan nilai awal pre tes dengan nilai akhir post tes dari kelompok eksperimen.

Untuk mengumpulkan data kelayakan produk pengembangan pada penelitian ini digunakan lembar validasi. Instrumen ini disusun menurut skala likert. Sesuai pendapat dari Riduwan, dalam (Sukariasih et al., 2019), skala likert dipakai dalam mengatur sikap, pendapat dan persepsi seseorang atau sekelompok mengenai kejadian atau gejala sosial. Hal ini secara spesifik telah ditetapkan oleh variabel penelitian. Skala likert memiliki empat alternatif jawaban. Dalam penelitian ini menggunakan kriteria: yaitu dengan keterangan berikut ini: sangat baik (bobot 4), baik (bobot 3), cukup baik (bobot 2) dan kurang baik (bobot 1).

Lembar validasi ini sesuai dengan pendapat Arikunto dalam (Marwiyah et al., 2019) diukur dengan rumus sebagai berikut:

$$
\mathrm{K}=\frac{\sum n i}{N} \times 100 \%
$$

Keterangan:

$\mathrm{K} \quad$ : Persentase skor yang diperoleh

$\sum n i$ : jumlah skor yang diperoleh

$N \quad$ : jumlah skor maksimal

Selanjutnya, hasil dari perhitungan tersebut dimasukan ke dalam tabel persentase sesuai dengan kriteria penerapan yaitu dengan menentukan persentase (\%) tertinggi dan persentase $(\%)$ terendah terlebih dahulu dengan menggunakan rumus sebagai berikut:

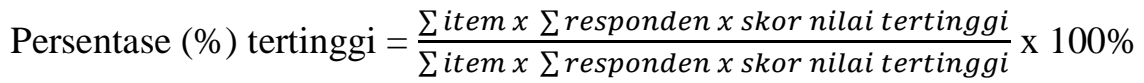

Persentase $(\%)$ terendah $=\frac{\sum \text { item } x \text { responden } x \text { skor nilai terendah }}{\sum \text { item } x \text { Eresponden } x \text { skor nilai tertinggi }} \times 100 \%$

Jika telah diperoleh persentase tertinggi dan terendah, selanjutnya yaitu menentukan interval kelas dengan rumus berikut ini:

Interval kelas $=\frac{\% \text { tertinggi } \% \text { terendah }}{\text { kelas yang dikehendaki }}$

$$
\begin{aligned}
& =\frac{100 \%-25 \%}{4} \\
& =18,75
\end{aligned}
$$

Berdasarkan hasil perhitungan yang diperoleh dan kelas yang dikehendaki berjumlah empat kelas interval maka selanjutnya dimasukan ke dalam tabel persentase sesuai dengan kriteria penilaian ahli seperti

\begin{tabular}{|c|c|}
\hline Interval (\%) & Kriteria \\
\hline $25<$ skor $\leq 43,75$ & Tidak layak \\
\hline $\begin{array}{l}43,75<\text { skor } \leq \\
62,50\end{array}$ & Kurang layak \\
\hline $\begin{array}{l}62,50<\text { skor } \\
81,25\end{array}$ & Layak \\
\hline
\end{tabular}
pada tabel berikut ini.

Tabel 1. Kriteria Penilaian Ahli Materi dan Ahli Media 
3503 Pengembangan E-Media Nearpod melalui Model Discovery untuk Meningkatkan Kemampuan Berpikir Kritis Siswa di Sekolah Dasar - Tri Adi Susanto

DOI: https://doi.org/10.31004/basicedu.v5i5.1399

$81,25<$ skor $\leq 100 \quad$ Sangat layak

Untuk mengetahui tingkat efektivitas pengembangan produk dilakukan dengan menggunakan Uji Skor ( $N$-gain). Menurut Hake dalam (Wahab et al., 2021), rumus mencari N-gain adalah sebagai berikut:

$$
\mathrm{g}=\frac{\text { spost }- \text { Spre }}{\text { Smax }- \text { Spre }}
$$

Keterangan:

g $\quad=$ N-Gain

Spost $=$ Skor Postes

Spre $\quad=$ Skor Pretes

Smax $=$ Skor Maksimum

Tabel 2. Kriteria Indeks Gain

\begin{tabular}{ccc}
\hline Skor & Kategori & Keterangan \\
\hline$(\mathrm{g}) \geq 0,70$ & Tinggi & Sangat efektif \\
\hline $0,70>(\mathrm{g}) \geq 0,30$ & Sedang & Efektif \\
\hline$(\mathrm{g})<0,30$ & Rendah & Tidak efektif \\
\hline
\end{tabular}

Selain itu, untuk menelaah apakah ada perbedaan atau tidak antara kemampuan awal (pre tes) dan kemampuan akhir (post tes) pada kelas eksperimen, dilakukanlah Uji t. Dalam pelaksanaannya, uji t ini menggunakan uji Paired Samples T-Test.

\section{HASIL DAN PEMBAHASAN}

\section{Hasil Pengembangan E-Media (Nearpod)}

Untuk pengembangan E-Media Nearpod, langkah-langkah yang dilakukan pada langkah pertama yaitu membuka alamat laman atau website nearpod.com pada halaman mesin pencari, dapat menggunakan google, googlechrome, microsoft edge maupun mozila firefox. Selanjutnya setelah masuk ke portal nearpod, silakan memilih daftar (Sign up for FREE) sebagai guru (Teacher). Siapkanlah sebuah email google aktif untuk mendaftar; (2) Klik daftar dengan akun/email google aktif (Sign Up with Google). Untuk mendaftar dengan akun google diperlukan persetujuan seperti terlihat pada gambar berikut ini. Centang kotak "I agree to Nearpod", kemudian klik "Sign Up". Jika sudah berhasil mendaftar dengan google, selanjutnya pilihlah aturan atau tipe akun. Karena kita guru, maka dipilih sebagai teacher. Proses pendaftaran selesai, jendela akan diarahkan pada halaman beranda Nearpod. Perhatikanlah perintah petunjuk awal penggunaan.

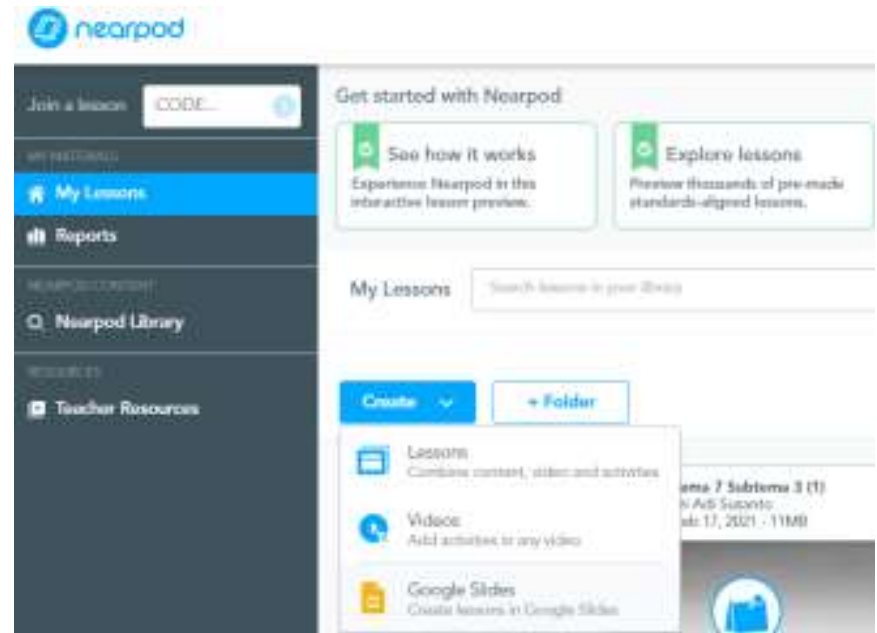

Gambar 1. Tampilan halaman beranda Nearpod 
3504 Pengembangan E-Media Nearpod melalui Model Discovery untuk Meningkatkan Kemampuan Berpikir Kritis Siswa di Sekolah Dasar - Tri Adi Susanto

DOI: https://doi.org/10.31004/basicedu.v5i5.1399

Untuk pengembangan nearpod sebagai E-Media dapat dilakukan dengan memilih my lessons dan creat untuk memulai pengembangan. Klik utitled lesson dan klik tombol add slide. Selanjutnya pilihlah content atau activities. Misanya kita pilih activities dan menu collaborate board maka akan muncul menu kegiatan yang dapat kita kembangkan. Jika sudah dipilih collaborate board maka akan muncul menu. Isilah bab atau sub bab yang di bahas pada menu "Enter Topic". Isilah keterangan atau deskripsi materi yang dibahas pada menu "Enter discription". Pilihlah gaya tampilan klik "choose a style". Selanjutnya untuk menyimpan klik "Save".

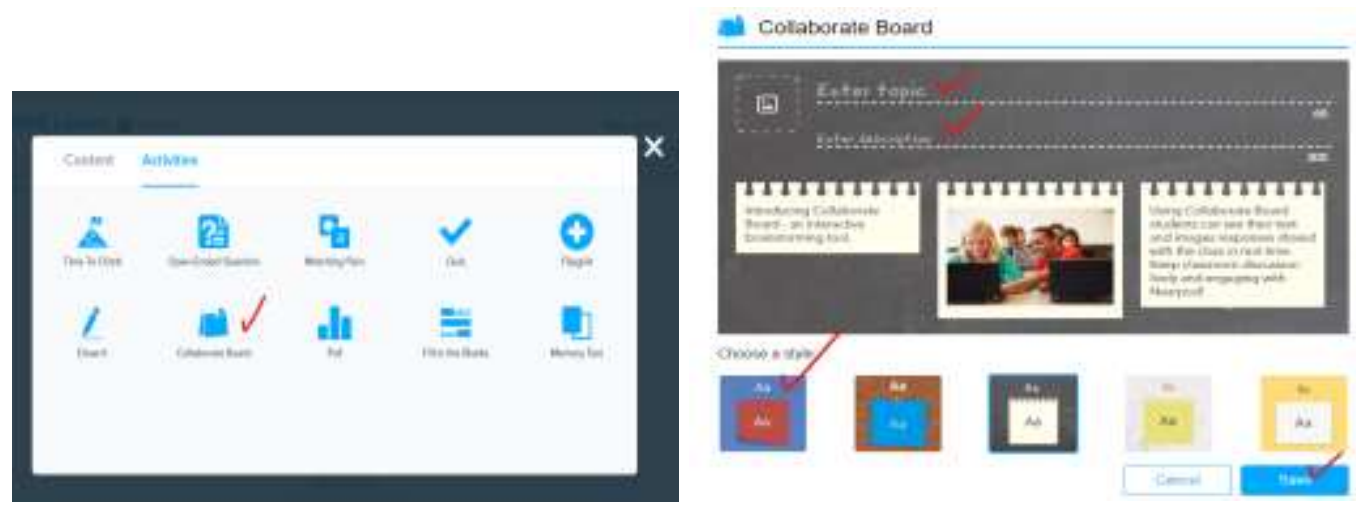

Gambar 2. Tampilan menu content atau activities dan menu collaborate board

Untuk mengunakan dalam pembelajaran, misalnya pada topik Tema 7 (Mupel IPA: Perubahan Wujud Benda), maka hasilnya nanti dapat dilihat pada preview. Setelah dibuat maka selanjutnya dapat dilihat pada menu preview sebagai berikut. Untuk menulis perintah kepada siswa dapat menuliskan pada toolbar "share throughts and/or image here" kemudian dikirimkan klik "post". Siswa nanti akan membaca apa yang kita kirimkan dan siswa bisa menanggapi.
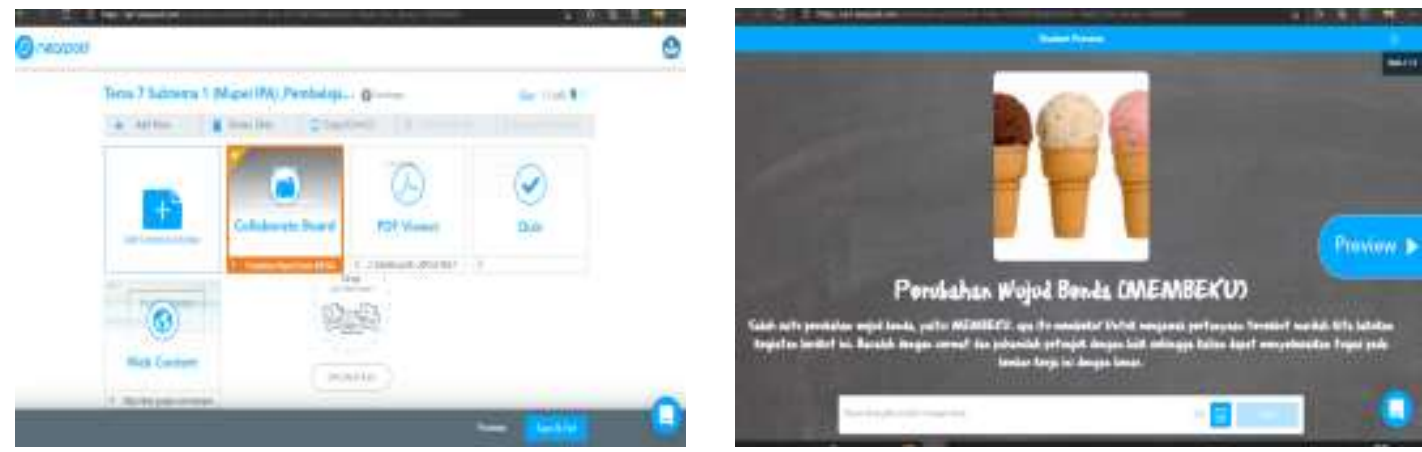

Gambar 3. Tampilan menu preview collaborate board

Guru dapat mengembangkan berbagai kegiatan dan menambahkan soal-soal atau quiz juga. Jika sudah selesai jangan lupa untuk menentukan kunci jawaban yang benar dan klik simpan "Save". Jika sudah selesai mengembangkan konten, langkah selanjutnya membagikan konten yang telah dibuat kepada siswa. Untuk membagikan konten yang telah kita buat, dapat dipilih tiga tipe, yaitu yang pertama secara langsung dikombinasikan dengan aplikasi zoom meeting klik "Live Participation + Zoom", kedua secara langsung tampa interaksi virtual "Live Participation" dan yang ketiga adalah daring asinkron dengan memilih "StudentPaced". Pilihan Student-Paced disesuaikan pada kondisi siswa tidak harus secara langsung namun siswa dapat memilih waktu untuk menyelesaikan konten yang diberikan secara leluasa. Dapat pula konten yang dikembangkan diedit lagi sebelum diberikan dengan memilih tombol "Edit". Untuk melihat tampilan dapat diklik tombol "Preview". Selanjutnya jika sudah yakin dan selesai, E-Media Nearpod dapat di tugaskan pada 
siswa dengan memilih salah satu tipe yaitu "Student-Paced". Tampilannya dapat dilihat pada gambar berikut ini.

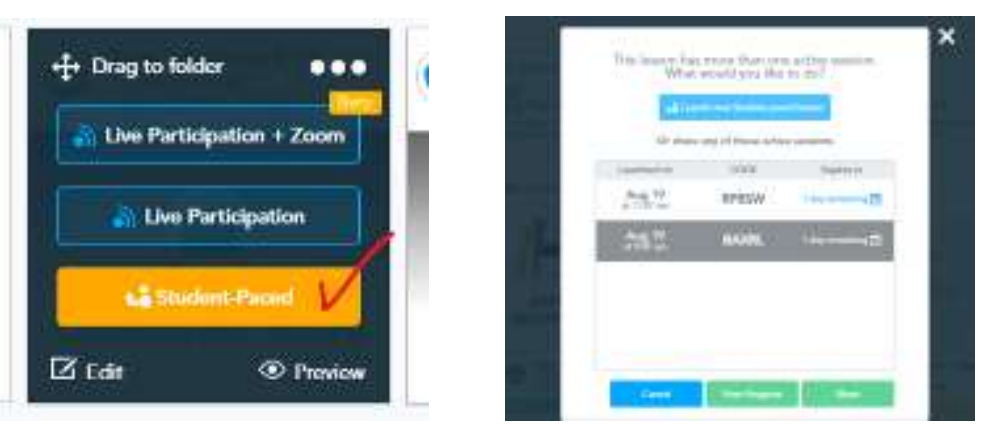

Gambar 4. Tampilan menu metode membagikan konten

Guru kemudian membagikan kode konten melalui berbagai platform seperti email, social media, link, URL, google classroom, dan Microsoft Time. Untuk yang paling mudah dapat dibagikan melalui link (tautan) yang diberikan. Link ini dapat dibagikan melalui WAG, Telegram dan Discord. Untuk melihat kemajuan apakah sudah dibuka dan dikerjakan oleh siswa, maka dapat diklik tombol "View Progress". Guru dapat memantau hasil pekerjaan siswa. Jika dirasa masih belum baik maka dapat diulang lagi agar dapat meningkat.

Guru memberikan evaluasi akhir untuk mengukur kemampuan siswa dalam menyelesaikan soal-soal IPA yang telah dibuat yang sesuai indikator berpikir kritis. Soal dapat dibuat berup pilihan multiple coice, isian singkat maupun open ended. Untuk mengukur kemampuan berpikir kritis ini diberikan soal dengan bentuk open ended. Adapun indikator berpikir kritis yang diukur yaitu: memberikan penjelasan sederhana (elementery clarification), membangun keterampilan dasar (basic support), menyimpulkan (inference), membuat penjelasan lebih lanjut (advanced clarification) dan strategi dan taktik (strategies and tactics).
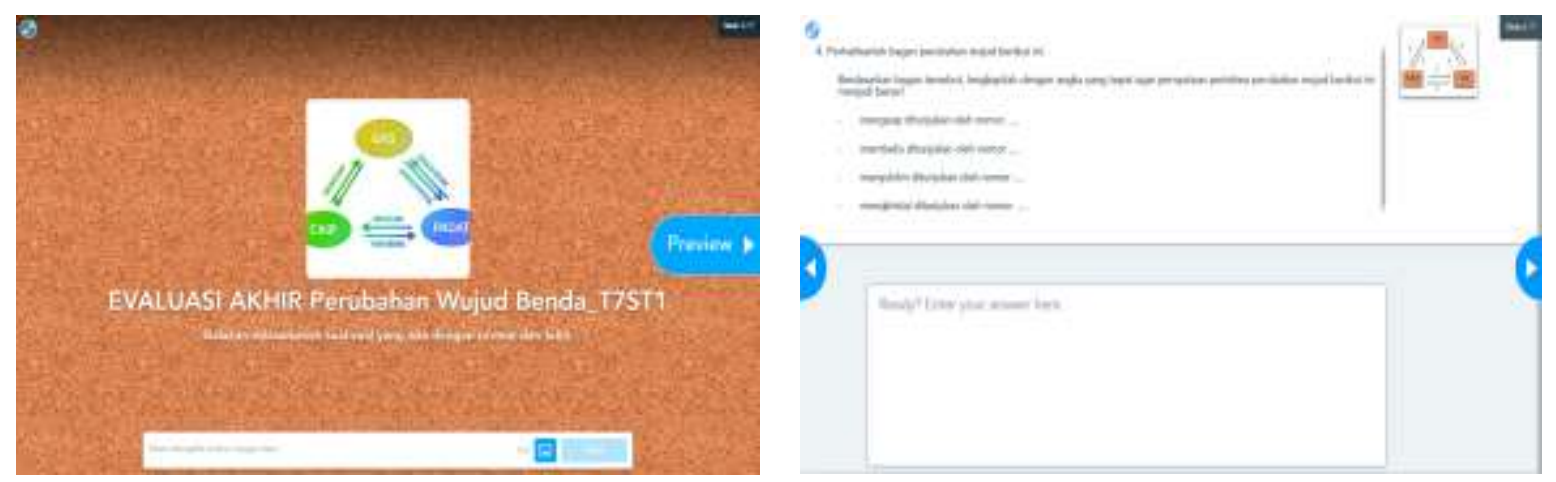

Gambar 5. Tampilan menu evaluasi akhir dan bentuk soal open ended

\section{Hasil Pengembangan Bahan Ajar dan Evaluasi untuk Konten Nearpod}

Untuk pengembangan bahan ajar untuk pengembangan E-Media Nearpod yang digunakan dalam pembelajaran, pertama-tama kita merancang bahan ajar yang meliputi kompetensi, materi, lembar kerja dan tes formatif serta kelengkapan yang lain. Dilanjutkan membuat sampul atau cover bahan ajar yang didesain sedemikian rupa, membuat desain keterangan penulis, ahli media, ahli materi, dan tata letak serta layout, menuliskan prakata, menuliskan daftar isi dari bahan ajar dan membuat desain peta konsep. 

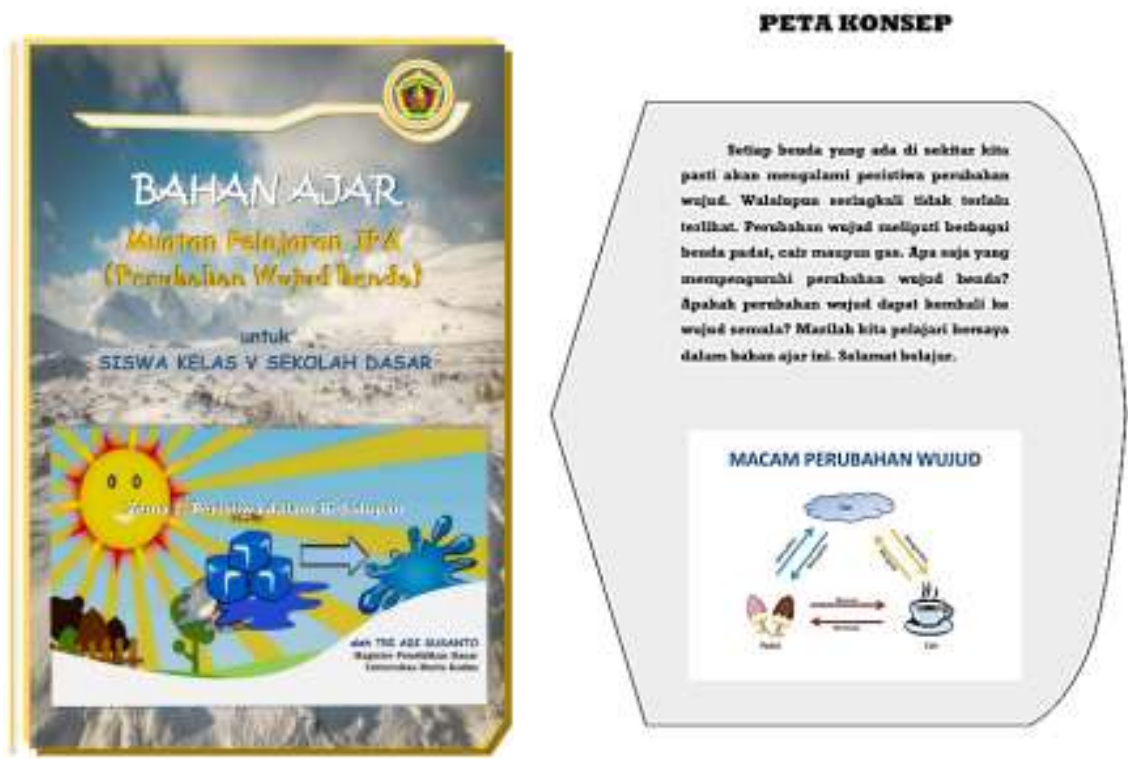

Gambar 6. Desain cover dan peta konsep

Pada isi bahan ajar, berisi pembelajaran dari pembelajaran I dan seterusnya sampai dengan pembelajaran V. Pada halaman ini berisi mengenai pokok materi yang dipelajari, kompetensi dasar, indikator, alokasi waktu dan tujuan pembelajaran. Pada halaman 2, kita memasuki ke materi. Pada materi berisi pemaparan sedikit pengetahuan awal untuk menuju ke kegiatan selanjutnya. Halaman selanjutnya yaitu lembar kerja. Di halaman ini berisi kegiatan eksperimen yang harus dilakukan oleh siswa dengan langkahlangkah model discovery. Isi dari lembar kerja ini meliputi: (1) Simulation; (2) Problem Statement; (3) Data Collection; (4) Data Processing; (5) Verification; Dan (6) Generalization. Berikut ini tampilannya.
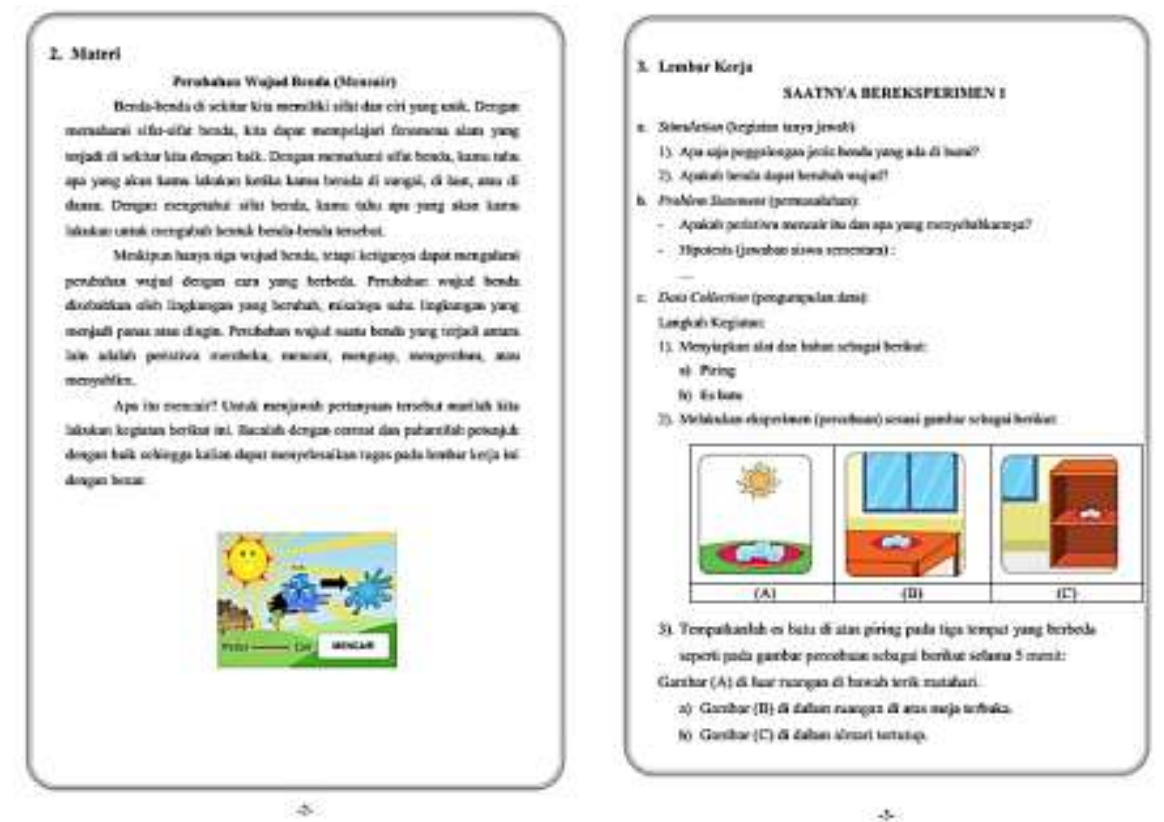

Gambar 7. Desain halaman materi bahan ajar dan halaman lembar kerja

Pada halaman tes formatif dengan soal-soal yang telah disediakan dengan dilengkapi kunci jawaban dan pedoman penilaian. Selain itu, bahan ajar ini juga dilengkapi evaluasi akhir. Untuk desainnya ditampilkan berikut ini. 
3507 Pengembangan E-Media Nearpod melalui Model Discovery untuk Meningkatkan Kemampuan Berpikir Kritis Siswa di Sekolah Dasar - Tri Adi Susanto

DOI: https://doi.org/10.31004/basicedu.v5i5.1399
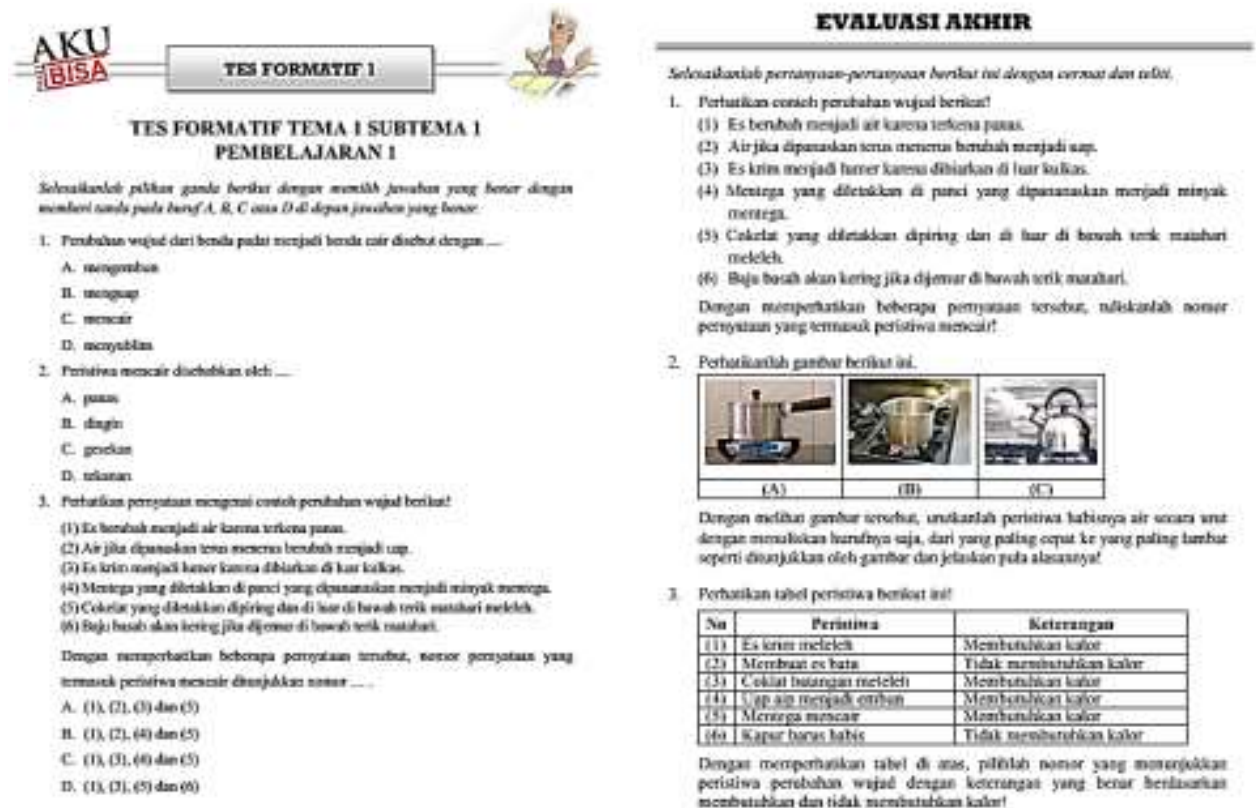

Gambar 8. Desain halaman tes formatif dan evaluasi akhir

Pada bagian penutup dilengkapi dengan daftar pustaka, sedangkan untuk sampul atau halaman akhir atau cober belakang dilengkapi dengan biografi penulis. Adapun desain dari cover belakang dapat dilihat pada gambar berikut ini.
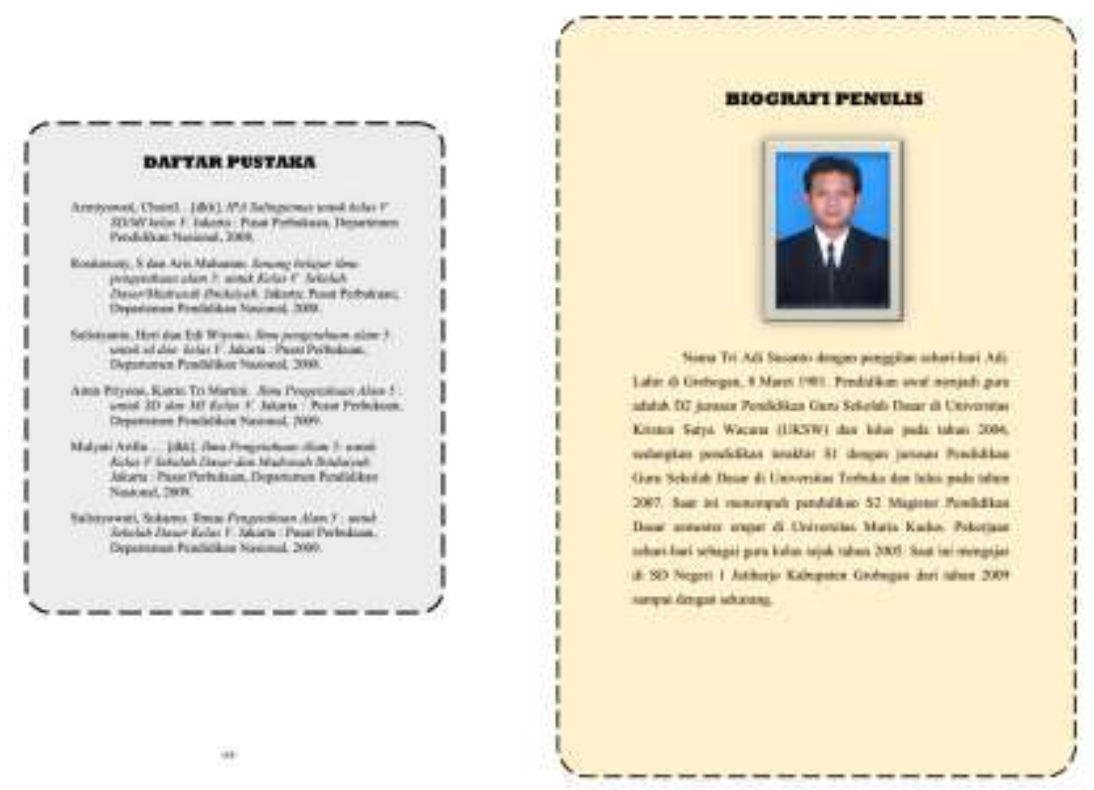

Gambar 9. Desain daftar pustaka bahan ajar dan cover belakang bahan ajar

\section{Validasi Hasil Pengembangan E-Media (Nearpod) oleh Ahli Materi dan Ahli Media}

Validasi oleh ahli materi dilakukan dengan tujuan mengkonsultasikan tentang materi yang dikembangkan kepada para ahli (dosen, pendidik diprioritaskan pada bidang pendidikan). Langkah yang dilakukan yaitu validator ahli materi yang terdiri atas akademisi dan praktisi pendidikan dengan aspek yang dinilai adalah aspek pembelajaran, aspek penyajian materi, dan aspek bahasa dan komunikasi. Validasi ini dilakukan untuk mengetahui apakah pengembangan E-media Nearpod ini, secara kualitas materi, layak 
3508 Pengembangan E-Media Nearpod melalui Model Discovery untuk Meningkatkan Kemampuan Berpikir Kritis Siswa di Sekolah Dasar - Tri Adi Susanto

DOI: https://doi.org/10.31004/basicedu.v5i5.1399

digunakan di kelas $\mathrm{V}$ jenjang sekolah dasar. Berdasarkan hasil validasi materi yang dilakukan diperoleh rangkuman hasil yang dapat dilihat pada tabel 3 berikut ini.

Tabel 3. Rangkuman Hasil Validasi Pengembangan E-Media (Nearpod) oleh Ahli Materi

\begin{tabular}{ccclc}
\hline No. & Aspek & $\begin{array}{c}\text { Capaian Persentase per } \\
\text { Aspek }\end{array}$ & Kriteria & Keterangan \\
\hline 1. & Pembelajaran & $84 \%$ & Sangat layak & dengan revisi \\
\hline 2. & Penyajian Materi & $88 \%$ & Sangat layak & tanpa revisi \\
\hline 3. & Bahasa dan Komunikasi & $83 \%$ & Sangat layak & dengan revisi \\
\hline & Keseluruhan & $85 \%$ & Sangat layak & dengan revisi \\
\hline
\end{tabular}

Berdasarkan tabel tersebut, secara keseluruhan pengembangan E-Media (Nearpod) menunjukkan hasil positif di mana persentase mencapai $85 \%$ kategori sangat valid dengan keterangan layak dengan revisi.

Validasi oleh ahli media dilakukan dengan tujuan untuk mengkonsultasikan tentang media yang dikembangkan kepada para ahli (dosen, pendidik diprioritaskan pada bidang komputerisasi atau yang sepadan). Untuk validasi pengembangan E-Media Nearpod oleh ahli media, langkah yang dilakukan yaitu validator media mengisi lembar instrumen yang terkait dengan ahlinya, validator ahli media yang terdiri dari dosen dan praktisi atau pendidik yang ahli dalam bidang komputerisasi, dengan aspek penilian sebagai berikut: aspek navigasi (petunjuk), aspek operasional, aspek tulisan (teks), dan aspek tampilan. Validasi ini dilakukan untuk mengetahui apakah pengembangan E-media (nearpod) ini, secara kualitas media, layak digunakan di kelas $\mathrm{V}$ jenjang sekolah dasar. Berdasarkan hasil validasi media yang dilakukan diperoleh rangkuman hasil yang dapat dilihat pada tabel 4 berikut ini.

Tabel 4. Hasil Validasi Pengembangan E-Media (Nearpod) oleh Ahli Media

\begin{tabular}{ccclc} 
No. & Aspek & $\begin{array}{c}\text { Capaian Persentase } \\
\text { per Aspek }\end{array}$ & Kriteria & Keterangan \\
\hline 1. & Navigasi (Petunjuk) & $88 \%$ & Sangat layak & tanpa revisi \\
\hline 2. & Operasional & $85 \%$ & Sangat layak & dengan revisi \\
\hline 3. & Tulisan (teks) & $83 \%$ & Sangat layak & dengan revisi \\
\hline 4. & Tampilan & $83 \%$ & Sangat layak & dengan revisi \\
\hline & Keseluruhan & $84 \%$ & Sangat layak & dengan revisi \\
\hline
\end{tabular}

Secara keseluruhan, pengembangan E-Media (Nearpod) menunjukkan hasil positif di mana persentase mencapai $84 \%$ kategori sangat valid dengan keterangan layak dengan revisi. Pengembangan E-media (nearpod) yang berisi bahan ajar dengan model discovery telah divalidasi oleh ahli yang berkompeten di bidangnya. Validasi dilakukan oleh ahli materi dan oleh ahli media.

Pada beberapa aspek yang telah dipaparkan, secara ringkas saran yang diberikan oleh para validator ahli tersebut yaitu: (1) Tambahkan orientasi dan motivasi dalam kegiatan pembelajaran; (2) Kegiatan pembelajaran dikaitkan dengan kegiatan sehari-hari; (3) Bahan ajar dilengkapi dengan glosarium; (5) Tulisan dipilih yang memiliki style mudah dibaca dan kontras; dan (6) Menggunakan warna yang menarik dan layout ramah penglihatan. Itulah beberapa hal yang diperbaiki agar E-Media (nearpod) semakin berkualitas. Kesimpulan dari hasil kelayakan E-Media (nearpod) yang dikembangkan adalah sangat layak dengan sedikit revisi. 


\section{Hasil Uji Efektivitas Pengembangan E-Media (Nearpod) melalui Model Discovery untuk Meningkatkan Kemampuan Berpikir Kritis Siswa}

Mengenai analisis hasil penelitian untuk mengetahui tingkat efektivitas E-media (nearpod) melalui model discovery dalam meningkatkan kemampuan berpikir kritis dapat dibahas bahwa dari hasil analisis pre tes kelas eksperimen, yang berupa soal evaluasi untuk mengukur kemampuan berpikir kritis, rata-rata kemampuan berpikir kritis adalah 65,18 dengan nilai tertinggi 85 dan nilai terendah 55. Dari pengitungan analisis rata-rata ini diperoleh nilai varian $\left(\mathrm{s}^{2}\right)$ 58,00 dan simpangan baku (s) 7,62. Setelah dilakukan post tes pada kelas eksperimen, diperoleh peningkatan rata-rata berpikir kritis menjadi 79,74 dengan nilai tertinggi 95 dan nilai terendah 70. Nilai varian ( $\mathrm{s}^{2}$ ) 31,63 dengan simpangan baku atau standar deviasi (s) 5,62.

Untuk lebih memperjelas paparan mengenai pembahasan hasil efektivitas E-media (nearpod) melalui model discovery dalam pembelajaran untuk meningkatkan kemampuan berpikir kritis dapat dilihat pada tabel 5. berikut ini.

Tabel 5. Hasil Kemampuan Berpikir Kritis Pre Tes dan Post Tes pada Kelas Eksperimen

\begin{tabular}{ccc}
\hline Perbandingan & Pre Tes & Post Tes \\
\hline Nilai rata-rata kemampuan berpikir kritis & 65,18 & 79,74 \\
\hline Nilai Tertinggi & 85 & 95 \\
\hline Nilai Terendah & 55 & 70 \\
\hline
\end{tabular}

Selanjutnya dari data tersebut dilakukan uji skor ( $N$-gain) untuk mengetahui tingkat efektivitas pengembangan produk. Kita masukkan nilai yang ada pada rumus di bawah ini.

$$
\begin{aligned}
\mathrm{g} & =\frac{\text { Spost-Spre }}{\text { Smax }- \text { Spre }} \\
& =\frac{79,74-65,18}{100,00-65,18} \\
& =\frac{14,56}{34,82} \\
& =0,42
\end{aligned}
$$

Dari hasil perhitungan $N$-gain tersebut yaitu dengan membandingkan rata-rata kemampuan berpikir kritis pre tes dan post tes diperoleh hasil gain $(\mathrm{g})=0,42$ dengan kriteria sedang sehingga E-media (nearpod) termasuk efektif dalam meningkatkan kemampuan berpikir kritis siswa.

Adapun dari hasil uji t yang menggunakan uji Paired Samples T-Test dilakukan perhitungan dari uji perbedaan rata-rata dari pre tes dan post tes peningkatan kemampuan berpikir kritis siswa. Dari perhitungan analisis efektivitas dengan dengan uji-t (paired sampel-tes), diperoleh hasil signifikansi (Sig. (2-tailed)) skor pretest dan posttest kelas eksperimen adalah 0,000 karena nilai sig. $0,000<\alpha 0,05$, dan , sedangkan penghitungan nilai $-\mathrm{t}_{\text {hitung }}-6,38913<-\mathrm{t}_{\text {tabel }}-1,66864$ maka $\mathrm{H}_{\mathrm{o}}$ ditolak sehingga menerima $\mathrm{H} 1$ yang artinya terdapat perbedaan yang signifikan antara rata-rata kemampuan berpikir kritis awal (pretest) dan kemampuan berpikir kritis akhir (posttest) kelas eksperimen. Berdasarkan hasil tersebut terdapat peningkatan kemampuan berpikir kritis siswa setelah diberikan perlakuan menggunakan E-media Nearpod melalui model Discovery.

Dalam penerapan E-media Nearpod melalui model Discovery dalam pembelajaran Tema 7 muatan pelajaran IPA dengan topik perubahan wujud benda, guru dapat mengaplikasikan langkah-langkah dari model discovery yang meliputi: (1) Simulation; (2) Problem statement; (3) Data collection; (4) Data processing; (5) Verification; dan (6) Generalization. Melalui pembelajaran ini, hal baru dapat diperoleh siswa karena harus belajar secara mandiri secara daring. Dengan penggunaan media yang berupa E-media Nearpod dapat membuat siswa lebih paham dengan berbagai fitur yang berupa link video, bahan ajar yang ditampilkan berupa file yang dapat diunduh di laptop dan HP. Demikian pula dapat diintegrasikan dengan website dan presensi melalui google doc dan soal evaluasi dikerjakan secara daring. Melalui penelitian juga membuat 
siswa akhirnya dapat menyesuaikan dengan pembelajaran yang ada, yaitu secara daring dan luring atau gabungan keduanya.

Hasil penelitian yang memuat bahwa E-media Nearpod ini juga didukung oleh pendapat yang dikemukanan dalam (Sanmugam et al., 2019) bahwa melalui Nearpod yang berbasis web yang memungkinkan siswa untuk terlibat dengan guru selama pembelajaran. Beberapa fitur interaktif dapat ditambahkan dalam perangkat lunak Nearpod dan materi dapat disiarkan ke perangkat siswa melalui internet. Melalui penerapan software Nearpod dan perancangan presentasi menggunakan Nearpod dapat mendukung pembelajaran siswa. Berdasarkan pendapatnya Nearpod diperkenalkan sebagai metode belajar mengajar terutama di kelas besar untuk mendorong interaksi dan melakukan pembelajaran mandiri pada siswa.

Untuk penerapan pembelajran melalui model Discovery dalam pembelajaran ada hasil penelitian yang mendukung yaitu dari (Putra et al., 2017) di mana, dari penelitiannya diperoleh bahwa dengan menggunakan model discovery learning sebagai tahapan dalam setiap kegiatan belajar mengajar, terbukti mampu menumbuhkembangkan keaktifan siswa dan kemandirian siswa dalam kegiatan belajar mengajar di kelas. Penelitian dari (Oktaviani, 2018) juga memberikan hasil bahwa model pembelajaran Discovery Learning (DL) dapat meningkatkan kemampuan berpikir kritis dan hasil belajar matematika kelas 5 SD Negeri 3 Nambuhan. Selain itu, hasil lain yang sejalan yaitu penelitian dari (Haryanti \& Saputro, 2016). Dari penelitian tersebut diperoleh hasil bahwa pengembangan modul matematika berbasis discovery learning berbantuan flipbook maker untuk meningkatkan kemampuan pemahaman konsep siswa pada materi segitiga layak digunakan oleh siswa.

Penelitian pengembangan E-media Nearpod melalui model Discovery dalam pembelajaran ini juga memiliki keterbatasan karena hanya diterapkan di sekolah dasar di wilayah Desa Jatiharjo Kabupaten Grobogan dan hanya meneliti kelayakan media dan efektivitas dalam meningkatkan kemampuan berpikir kritis saja. Mungkin jika diterpkan di wilayah lain atau kondisi yang berbeda dapat memperoleh hasil yang berbeda. Namun demikian hasil penelitian ini dapat memberikan sumbangan pemikiran bahwa pengembangan E-media Nearpod melalui model discovery dapat meningkatkan kemampuan berpikir kritis siswa kelas V sekolah dasar walaupun terbatas di suatu wilayah tertentu. Harapannya dari hasil penelitian ini dapat memberikan inspirasi dan inovasi pembelajaran dalam bidang yang sama maupun bidang keilmuan yang berbeda.

\section{KESIMPULAN}

Dari hasil penelitian pengembangan yang berupa E-media Nearpod dapat diambil kesimpulan bahwa produk yang dikembangkan yang berupa E-media Nearpod setelah divalidasi oleh validator ahli memperoleh hasil sangat layak sehingga dapat dikembangkan dan digunakan maka dari itu E-media Nearpod merupakan alternatif media yang dapat dipakai oleh guru dalam pembelajaran muatan mata pelajaran IPA ataupun muatan mata pelajaran yang lain. Selain itu, dari hasil uji efektivitas penggunaan produk dapat disimpulkan bahwa Emedia Nearpod melalui Model Discovery yang diterapkan dalam pembelajaran dapat meningkatkan kemampuan berpikir kritis siswa sehingga dapat dinyatakan media jenis ini efektif.

\section{UCAPAN TERIMA KASIH}

Pada kesempatan ini, penulis menyampaikan terima kasih pertama kepada Tuhan Yang Maha Esa yang selalu memberikan rahmat dan anugerah-Nya, kedua kepada Dr. Sri Utaminingsih, M.Pd. selaku Ketua Program Studi Magister Pendidikan Dasar, ketiga kepada Dr. Irfai Fathurohman, S.Pd., M.Pd. dan Dr. Rismiyanto, M.Pd. selaku Dosen Pembimbing yang telah membimbing dalam menyelesaikan penulisan hasil 
3511 Pengembangan E-Media Nearpod melalui Model Discovery untuk Meningkatkan Kemampuan Berpikir Kritis Siswa di Sekolah Dasar - Tri Adi Susanto

DOI: https://doi.org/10.31004/basicedu.v5i5.1399

penelitian dan pengembangan ini dan yang terakhir terima kasih kepada Istri dan Anak-anakku tercinta yang selalu memberikan dukungan dan doa sehingga dapat menyelesaikan tulisan ini dengan baik.

\section{DAFTAR PUSTAKA}

Ananda, R. (2017). Penggunaan Media Audio Visual Untuk Meningkatkan Hasil Belajar Pendidikan Kewarganegaraan Siswa Kelas IV SD Negeri 016 Bangkinang Kota. Jurnal Basicedu, 1(1). Https://Doi.Org/10.31004/Basicedu.V1i1.149

Hagi, N. A., Koeswanti, H. D., \& Radia, E. H. (2019). Peningkatan Kemampuan Berpikir Kritis Melalui Model Problem Based Learning Pada Muatan Matematika Kelas V SDN Salatiga 01. Jurnal Basicedu, 3(1). Https://Doi.Org/10.31004/Basicedu.V3i1.68

Handayani, P., \& Koeswanti, H. D. (2020). Pengembangan Media Komik Untuk Meningkatkan Minat Membaca Siswa Sekolah Dasar. Jurnal Basicedu, 4(2). Https://Doi.Org/10.31004/Basicedu.V4i2.365

Haryanti, F., \& Saputro, B. A. (2016). Pengembangan Modul Matematika Berbasis Discovery Learning Berbantuan Flipbook Maker Untuk Meningkatkan Kemampuan Pemahaman Konsep Siswa Pada Materi Segitiga. Kalamatika Jurnal Pendidikan Https://Doi.Org/10.22236/Kalamatika.Vol1no2.2016pp147-161

Herliana, S., \& Anugraheni, I. (2020). Pengembangan Media Pembelajaran Kereta Membaca Berbasis Kontekstual Learning Siswa Sekolah Dasar. Jurnal Basicedu, 4(2). Https://Doi.Org/10.31004/Basicedu.V4i2.346

Kusumayadi, F. (2020). Pengaruh Disiplin Kerja Terhadap Prestasi Kerja Pegawai Pada Dinas Kesehatan Kota Bima. Business Management And Entrepreneurship ..., 15(2).

Marwiyah, M., Rusijono, R., \& Arianto, F. (2019). The Development Of Cai Based Android In Solar System And Universe Topic For Tenth-Grade. Geosfera Indonesia, 4(2). Https://Doi.Org/10.19184/Geosi.V4i2.9824

Mubasiroh, S. L. (2013). Pengembangan Buku Pembelajaran Keterampilan Menulis Berbasis Pendekatan Proses Untuk Siswa Sma Dan Ma Kelas Xi. In Skripsi.

Musfiqon. (2012). Pengembangan Media Dan Sumber Belajar. Jakarta: PT. Prestasi Pusta Karya, August.

Mustika, Z. (2015). Urgenitas Media Dalam Mendukung Proses Pembelajaran Yang Kondusif. CIRCUIT: Jurnal Ilmiah Pendidikan Teknik Elektro, 1(1). Https://Doi.Org/10.22373/Crc.V1i1.311

Oktaviani, W. (2018). Penerapan Model Pembelajaran Discovery Learning Untuk Meningkatkan Kemampuan Berpikir Kritis Dan Hasil Belajar Matematika Siswa Kelas 5 Sd. Jurnal Basicedu, 2(2). Https://Doi.Org/10.31004/Basicedu.V2i2.137

Prasetiyo, G. E., \& Ginting, N. (2019). Pengembangan Media Pembelajaran Budaya Melayu Dengan Adobe Flash Berbasis Kearifan Lokal Di Sekolah Dasar. Jurnal Basicedu, 3(4). Https://Doi.Org/10.31004/Basicedu.V3i4.179

Putra, K. W. B., Wirawan, I. M. A., \& Pradnyana, G. A. (2017). Pengembangan E-Modul Berbasis Model Pembelajaran Discovery Learning Pada Mata Pelajaran "Sistem Komputer" Untuk Siswa Kelas X Multimedia Smk Negeri 3 Singaraja. Jurnal Pendidikan Teknologi Dan Kejuruan, 14(1). Https://Doi.Org/10.23887/Jptk.V14i1.9880

Riyanti, R. (2020). Efektivitas Penggunaan Perangkat Pembelajaran Project Based Learning (Pjbl) Terintegrasi STEM Berbasis E-Learning Untuk Meningkatkan Kemampuan Berpikir Kreatif. DWIJA CENDEKIA: Jurnal Riset Pedagogik, 4(2). Https://Doi.Org/10.20961/Jdc.V4i2.45276

Sanmugam, M., Selvarajoo, A., Ramayah, B., \& Lee, K. W. (2019). Use Of Nearpod As Interactive Learning Method. Inted2019 Proceedings, 1. Https://Doi.Org/10.21125/Inted.2019.2219 
3512 Pengembangan E-Media Nearpod melalui Model Discovery untuk Meningkatkan Kemampuan Berpikir Kritis Siswa di Sekolah Dasar - Tri Adi Susanto

DOI: https://doi.org/10.31004/basicedu.v5i5.1399

Siswa, K., Ix, K., Model, M., Pada, P., \& Pelajaran, M. (2012). Peningkatan Perilaku Berkarakter Dan Keterampilan Berpikir Kritis Siswa Kelas Ix Mtsn Model Padang Pada Mata Pelajaran Ipa-Fisika Menggunakan Model Problem Based Instruction Renol Afrizon. 1(22), 1-16. Http:/Www.Undana.Ac.Id/Jsmallfib_Top/Jurnal/Pendidikan/Pendidikan_2012/Peningkatan Perilaku Berkarakter Dan Keterampilan Berpikir.Pdf

Sudarsono, S., Abdurrahman, A., \& Rosidin, U. (2020). Pengembangan Cerita Bergambar Fisika Berbasis STEM Untuk Menumbuhkan Literasi Sains Pada Siswa SMP. Jurnal Pendidikan Fisika, 8(1). Https://Doi.Org/10.24127/Jpf.V8i1.2202

Sukariasih, L., Saputra, I. G. P. E., Ikhsan, F. A., Sejati, A. E., \& Nisa, K. (2019). Improving The Learning Outcomes Of Knowledge And Inquiry Skill Domain On Third Grade Students Of Smp Negeri 14 Kendari Through The Guided Inquiry Learning Model Assisted By Science Kit. Geosfera Indonesia, 4(2). Https://Doi.Org/10.19184/Geosi.V4i2.10097

Wahab, A., Junaedi, J., \& Azhar, M. (2021). Efektivitas Pembelajaran Statistika Pendidikan Menggunakan Uji Peningkatan N-Gain Di PGMI. Jurnal Basicedu, 5(2). Https://Doi.Org/10.31004/Basicedu.V5i2.845

Widhiyantoro, T., Indrowati, M., \& Probosari, R. M. (2012). The Effectiveness Of Guided Discovery Method Application Toward Creative Thinking Skill At The Tenth Grade Students Of Sma N 1 Teras Boyolali In The Academic Year 2011 / 2012. Pendidikan Biologi, 4(September), 89-99.

Yulianti, D., Purnomo, E., \& Pargito, P. (2014). Pengembangan Media Word Square Berbantu Kartu Uno Untuk Meningkatkan Kemampuan Berpikir Kritis. Jurnal Studi Sosial, 1. 